\title{
Problems of University Students in Speaking English during Classroom Participation
}

\author{
Syeda Sidra Nosheen ${ }^{1}$, Muzammila Akram², Muhammad Javed ${ }^{3}$
}

\begin{abstract}
Students' academic achievement is directly related to their active classroom participation. They learn their lesson actively, discuss their lecture with their peers and teachers, but speaking English language becomes the hurdle in their active participation. So, this study was designed to analyze the problems of the university students in classroom participation. The objectives of the study were; to find out the problems of university students in speaking English during classroom participation, and to enlist factors creating problems for students in speaking English during classroom participation. The study was descriptive in nature. The population of the study was all enrolled students of the Islamia University Bahawalpur. 400 students were selected by the researchers as the sample of study. Questionnaire was used to collect the data from selected sample. SPSS was used to calculate the percentage and mean score of the collected data. Findings of the study indicated that students feel problem because of insufficient vocabulary, grammar illiteracy, lack of confidence and environment does not support them for classroom participation. Furthermore, results of the study recommend that there must be extra classes for students to give them opportunity to speak English language, and there must be a rule that students must speak English language otherwise they will have to pay fine.
\end{abstract}

Keywords: English Language, Speaking Problems, Classroom Participation, University Level

\section{Introduction}

Language is the source of communication and interaction between human beings, by using language human being can send or receive the messages from each other. Every region and culture has different languages but English language has distinguishing place among other languages. In Pakistan, English

\footnotetext{
${ }^{1} \mathrm{PhD}$ Scholar, Department of Education, The Islamia University Bahawalpur, Pakistan Email: sidra.nosheen@ymail.com

${ }^{2}$ Assistant Professor, Department of Educational Training, The Islamia University Bahawalpur, Pakistan Email: muzammilamurad@yahoo.com

${ }^{3}$ Assistant Professor, Department of Education, The Islamia University of Bahawalpur, Pakistan, Email: muhammad.javed@iub.edu.pk
} 
language has the status of second language. English language teaching is not an easy task although in Pakistan English is the compulsory subject from class one to higher education level, but course content is mainly focused on the writing and reading skills of the students whereas speaking, listening and speaking skills are mostly neglected in the course content of English language. That is why, students face lots of problems in speaking English language specially, during classroom participation. There is no survival without English language in this era, without English there is no future of the students. Learning English language speaking is very common but it is a complex phenomenon to learn and teach English language (Al-Sibai, 2004). Good and fluent speakers of English language have better future than the other students; they have more opportunities for higher education and better jobs in Pakistan and abroad. Particular in Asian countries, most of the national and international organizations have set the English language speaking proficiency as a criterion for the recruitment of new staff in the organizations (Ayokanmbi, 2011).

Additionally, language is used to educate and remain connected to other people because the world has become the global village it is the need of time to learn and use English language at every stage. So, in educational institutions it is compulsory for the students to communicate and participate in class and use English language. Language learning is a process and exceptional gift which nature gives to human being. People learn mother language in home but with the passage of time they learn second language to fulfill the educational, professional and social requirements. It is observed that most of the students cannot communicate and participate in classroom activities because of speaking English language problems. It cannot be neglected that classroom participation affects the students' academic achievement positively. Yet in Pakistani educational setup students face lots of problems in speaking English language. For speaking English language enhancement role of an English teacher is very wide and important. Moreover, Sharma (2004) explored that teachers put emphasis on learning English language speaking but in educational system of Pakistan basic education of the students remains weak so, students feel hesitation in speaking English. Pakistan is diverse in the linguistic culture which is complicated because in the beginning, child learns the mother language in school going age child comes across Urdu language as medium of instruction and communication between the class mates and teachers. With the passage of time child begins to learn English in addition to Urdu language. Speaking English language is an important skill which requires heavy input in terms of language acquisition (Patsy \& Speada, 2011). 


\subsection{Statement of the Problem}

In Pakistani education system, our curriculum is not sufficient to develop the four basic skills of English language learning. The most neglected skill is speaking skill in our curriculum. Teachers are not trained to develop the students speaking skills. Because having fluency in speaking English language is necessary for the students to achieve the academic goals. Nunan (2003) elaborated that many factors have been identified such as lack of practice, a limited opportunity to speak and use of English language in daily life communication, traditional instructional method of teachers and delivered by unqualified teachers. The purpose of this study was to investigate, what are the problems of university students' in speaking English during classroom participation.

\subsection{Objectives of the Study}

The objectives of the study were as follows;

1. To find out the problems of university students in speaking English during classroom participation.

2. To enlist factors affecting the students in speaking English during classroom participation.

\section{Literature Review}

Boonkit (2010) presented the work related to development of speaking skills for non-native speakers of English. For the effective communication, speaking skill is the basic skill for the language development. Furthermore, English is a second language for which environment and pedagogy play the vital role to enhance the speaking skills. It is considered as the most critical question among instructors that they can improve the speaking competence and confidence among students. So, this concern led researchers towards qualitative research design and an action research during classroom situation. Additionally, Kocak (2010) elaborated the anxiety among the trainee teachers of English language. The research aimed to minimize the anxiety among the trainee teachers and provided them better ways to improve their teaching of English language. Moreover, Gan (2012) explored the problem of speaking English language skills of second language learners at a teacher training institution in Hong Kong. The study highlighted the gap to understand the problems of ESL learning faced during development of oral English language courses. They found inadequate opportunities to speak English language in tutorials; in addition learners face the high range of problems those are related to the interpersonal, institutional and socio-cultural. Furthermore, Liu and Jackson (2008) elaborated that Chinese English language learners face the problems in speaking English language 
because they have insufficient English vocabulary. Moreover, according to Zhang (2009) speaking is considered as the most effort taking skill to master but most of the learners of English language are incompetent to communicate orally by using English language with others.

Yegani and Jodaei (2017) elaborated that task and topic-based speaking activities can help the learners those feel shy and low confidence during speaking English language and it is considered as one of the reasons that students fail to speak and discuss during class. Moreover, most of the students do not have exposure of effective speaking situations, however, task and topic-based speaking activities can involve and motivate the students to discuss their feelings, preferences, ideas and knowledge of the subjects to be discussed because it will be performed in small groups and will help the learners to enhance their speaking skills by motivation and minimize the stress level of the learners and provide various opportunities for speaking activities by use of group activities. Additionally, task and topic-based speaking activities can motivate the students for negotiation for completion of activities during classroom. Furthermore, in order to get significant results it is necessary to use these activities for long period in English language learning classes. According to Brantmier (2008) English teachers may apply the most effective strategy for developing speaking skills of the students and provide the appropriate time to practice the speaking skills with their class fellows and enhance the fluency in speaking English language.

Additionally, Wolff \& Qiang (2009) highlighted that most of the students face problems in speaking English, because they never practice English language speaking during English language learning process as they learn their native language. So, majority of them face lack of self-confidence during speaking with others. In addition, it is elaborated that students belonging to rich families can speak English more fluently than others. It is initial for the overseas students to learn English language for survival but they have to face lots of problem for English language speaking competency. Technological revolution has drastically changed the entire world and educational system, and teaching and learning of any foreign language has become easier for the learners and teachers. Application of multimedia-based programs has improved the traditional classroom into the more effective and interesting one for the learners and also changed the classroom based teaching learning process into an online face to face session, and it is proving as powerful teaching medium for the teachers and learners (Hartsell, 2016). According to Teng and Sinwongsuwat (2015), fluency in speaking English language is the most important and initial step during speaking English language, but it is not an easy task to achieve. Additionally, ineffective English 
curriculum and traditional teaching methods, which mostly emphasize on grammatical rules and structure, are responsible for failure in achieving the goals of communications.

\subsection{Research Design}

\section{Research Methodology}

According to the nature of the study to investigate the problems of university students in speaking English during classroom participation, quantitative research design was used.. So, researchers applied survey method to collect the data from selected sample for the current study.

\subsection{Population of Study}

The population of the study was enrolled students of the Islamia University of Bahawalpur in session 2017-18. The study was delimited to the students of all departments of the Islamia University of Bahawalpur.

\subsection{Sample \& Sampling Technique}

Sample included 400 university students which were selected randomly.

\subsection{Instrumentation}

A questionnaire was developed through focused group discussion with the eminent teachers keeping in view the objectives of the study. Questionnaire was based on 24 closed ended statements. Each item was rated on five point Likert scale from strongly agree (SA) to strongly disagree (SDA). The first draft of the questionnaire was discussed with the research experts and some amendments were made according to their recommendations in light of the objectives of study. Afterwards, the questionnaire was pilot tested on a sample of 120 university students that were not the part of selected sample. The computed Cronbach's alpha coefficient was 0.8 which is above the brink value of 0.7 hence the research questionnaire was trustworthy.

\subsection{Data Collection}

The researchers personally collected data from the university students by using questionnaire. The researchers observed ethics of research in social sciences.

\subsection{Data Analysis}

The quantitative data were coded and calculated using Statistical Package for Social Sciences (SPSS). The percentage and mean of each item was calculated. On the basis of the data results of the study were drown. 
Table 4.1

\section{Data Analysis \& Interpretation}

Vocabulary of English Language

\begin{tabular}{|c|c|c|c|c|c|c|c|c|}
\hline $\begin{array}{l}\mathrm{S} \\
\#\end{array}$ & Items & Options & SDA & $\mathrm{DA}$ & UN & A & SA & Mean \\
\hline \multirow[t]{2}{*}{1.} & \multirow{2}{*}{$\begin{array}{l}\text { I have rich vocabulary of } \\
\text { English language. }\end{array}$} & $\mathrm{f}$ & 104 & 208 & 46 & 32 & 5 & \multirow[t]{2}{*}{2.09} \\
\hline & & $\%$ & 26 & 25 & 11.5 & 8 & 1.25 & \\
\hline \multirow[t]{2}{*}{2.} & \multirow{2}{*}{$\begin{array}{l}\text { I can use appropriate English } \\
\text { vocabulary according to topic } \\
\text { of discussion. }\end{array}$} & f & 118 & 194 & 48 & 40 & 00 & \multirow[t]{2}{*}{2.03} \\
\hline & & $\%$ & 29.5 & 48.5 & 12 & 10 & 0 & \\
\hline \multirow[t]{2}{*}{3.} & \multirow{2}{*}{$\begin{array}{l}\text { I use simple vocabulary of } \\
\text { English during classroom } \\
\text { participation. }\end{array}$} & $\mathrm{f}$ & 14 & 64 & 62 & 84 & 228 & \multirow[b]{2}{*}{4.26} \\
\hline & & $\%$ & 3.5 & 16 & 15.5 & 21 & 57 & \\
\hline \multirow[t]{2}{*}{4.} & \multirow{2}{*}{$\begin{array}{l}\text { Insufficient English } \\
\text { vocabulary creates hurdles for } \\
\text { students in speaking English } \\
\text { language. }\end{array}$} & $\mathrm{f}$ & 2 & 9 & 20 & 187 & 182 & \multirow[t]{2}{*}{4.35} \\
\hline & & $\%$ & 0.5 & 2.3 & 5 & 46.8 & 45.5 & \\
\hline
\end{tabular}

Table 4.1, Statement no 1 shows that $26 \%$ respondents strongly disagreed, $25 \%$ disagreed, $11.5 \%$ uncertain, $8 \%$ agreed and just $1.5 \%$ strongly agreed that they have rich vocabulary of English language. Mean score 2.09 presented that majority of the respondents disagreed that they have rich vocabulary. Moreover, statement no 2 shows that $29.5 \%$ respondents strongly disagreed, 48.5\% disagreed, 12 uncertain, $10 \%$ agreed and $0 \%$ respondents strongly agreed that they can use appropriate English vocabulary according to the topic of discussion. Furthermore, 3.5\% respondents strongly disagreed, $16 \%$ disagreed with the statement, $15.5 \%$ uncertain, $21 \%$ agreed whereas $57 \%$ strongly agreed that they use simple vocabulary during classroom discussion. 4.26 mean score also supported that majority of students use simple vocabulary. Statement no 4 indicates that the $0.5 \%$ respondents strongly disagreed, $2.3 \%$ disagreed, $5.0 \%$ uncertain, 46.8 agreed and $45.5 \%$ strongly agreed with statement that 'Insufficient English vocabulary creates hurdles for students in speaking English language'. Mean score 4.35 also supported the statements. So, majority of the respondents; $46.8 \%$ agreed that the problem is lack of vocabulary. 
Table 4.2

Grammatical Structure of English Language

\begin{tabular}{llccccccc}
\hline S\# & Items & Options & SDA & DA & UN & A & SA & Mean \\
\hline 1. & I follow the grammatical & $\mathrm{f}$ & 24 & 84 & 52 & 96 & 144 & 3.63 \\
& $\begin{array}{l}\text { structure of English during } \\
\text { classroom participation. . }\end{array}$ & $\%$ & 6 & 21 & 13 & 24 & 36 & \\
2. & $\begin{array}{l}\text { I am able to speak English } \\
\text { without grammatical mistakes. }\end{array}$ & $\mathrm{f}$ & 184 & 112 & 54 & 36 & 14 & 1.96 \\
& $\%$ & 46 & 28 & 13 & 9 & 3.5 & \\
3. & $\begin{array}{l}\text { Grammar illiteracy is the hurdle } \\
\text { for the students in class room } \\
\text { participation. }\end{array}$ & $\mathrm{f}$ & 5 & 26 & 40 & 189 & 140 & \\
\end{tabular}

Table 4.2 indicates that $6 \%$ respondents strongly disagreed, $21 \%$ disagreed $13 \%$ uncertain, $24 \%$ agreed and $36 \%$ strongly agreed with statement that 'they follow grammatical rules during classroom participation'. Mean score 3.36 described that majority of the respondents follow the grammatical rules. Statement no 2 shows that $46 \%$ respondents strongly disagreed, $28 \%$ disagreed, $13 \%$ uncertain, $9 \%$ agreed whereas just 3.5\% strongly agreed with statement that 'they are able to speak English without grammatical mistakes'. Mean score 1.96 described that majority of the respondents are not able to speak English without mistakes. Furthermore, $1.3 \%$ respondents strongly disagreed, $6.5 \%$ disagreed, $10 \%$ uncertain, $47.3 \%$ agreed and $35 \%$ strongly agreed with statement that 'Grammar illiteracy is the hurdle for the students in class room participation'. Mean score 4.08 also supported the statement. So majority of the respondents; $47.3 \%$ agreed that the problem is grammar illiteracy.

Table 4.3 Accent and Pronunciation of English Language

\begin{tabular}{llccccccc}
\hline S\# & Items & Options & SDA & DA & UN & A & SA & Mean \\
\hline 1. & I speak English language with & $\mathrm{f}$ & 134 & 150 & 70 & 34 & 12 & 2.10 \\
& proper accent. & $\%$ & 33.5 & 37.5 & 17.5 & 8.5 & 3 & \\
2. & $\begin{array}{l}\text { Mother tongue influences the } \\
\text { accent of students in speaking }\end{array}$ & $\mathrm{f}$ & 14 & 35 & 33 & 188 & 130 & 3.96 \\
& $\begin{array}{l}\text { English. } \\
\text { I use English words with proper }\end{array}$ & $\mathrm{f}$ & 52 & 116 & 92 & 70 & 86 & 3.10 \\
& pronunciation. & $\%$ & 13 & 29 & 23 & 17.5 & 21.5 & \\
4. & $\mathrm{f}$ & 5 & 26 & 40 & 189 & 140 & \\
& $\begin{array}{l}\text { Students try to speak English } \\
\text { with poor accent and } \\
\text { pronunciation during classroom }\end{array}$ & $\%$ & 1.3 & 6.5 & 10 & 47 & 35 & 4.08 \\
participation. & & & & & & & \\
Improper accent and & $\mathrm{f}$ & 5 & 43 & 50 & 180 & 122 & 4.35 \\
\hline
\end{tabular}




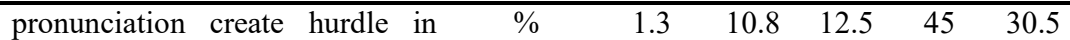
classroom participation.

Table 4.3 statement no 1 indicates that $33.5 \%$ respondents strongly disagreed, $37.5 \%$ disagreed, $17.5 \%$ uncertain, $8.5 \%$ agreed and $3 \%$ strongly agreed with statement that 'they speak English with proper accent'. Mean score 2.10 also highlights that majority of the respondents disagree that they can speak English with proper accent. Furthermore, statement no 2 shows that the $3.5 \%$ respondents strongly disagreed, $8.8 \%$ disagreed, $8.3 \%$ uncertain, $47.0 \%$ agreed and $32.5 \%$ strongly agreed with statement that 'Mother tongue influences the accent of students in speaking English'. Mean score 3.96 also supported the statement. So, majority of the respondents $47.0 \%$ agreed that the Mother tongue affects the accent. Statement 3 indicates that $13 \%$ respondents strongly disagreed, $29 \%$ disagreed, $23 \%$ uncertain, $17.5 \%$ agreed and $21.5 \%$ strongly agreed with statement that 'they use English words with proper accent'. Mean score 3.10 elaborates that majority of the respondents are not able to use English word with proper pronunciation. Statement 4 indicates that $1.3 \%$ respondents strongly disagreed, $6.5 \%$ disagreed, $10 \%$ uncertain, $47 \%$ agreed and 35\% strongly agreed with statement that 'Students try to speak English with poor accent and pronunciation during classroom participation.' Mean score 4.08 also elaborates that majority of the respondents do efforts for speaking English language with poor accent and pronunciation. Statement 5 indicates that $1.3 \%$ respondents strongly disagreed, $10.8 \%$ disagreed, $12.5 \%$ uncertain, $45.0 \%$ agreed and $30.5 \%$ strongly agreed with statement that 'Improper accent and pronunciation create hurdle in classroom participation'. Mean score 4.35 also supported the statement. So, majority of the respondents; $45.0 \%$ agreed that the problem is improper accent and pronunciation. 
Table 4.4

Fluency in Speaking English

\begin{tabular}{llccccccc}
\hline S\# & Item & Options & SDA & DA & UN & A & SA & Mean \\
\hline 1. & I speak English language fluently & $\mathrm{f}$ & 202 & 96 & 58 & 34 & 10 & 1.89 \\
& during classroom discussion. & $\%$ & 50.5 & 24 & 15 & 9 & 2.5 &
\end{tabular}

Table 4.4 Statement 1 indicates that the $50.5 \%$ respondents strongly disagreed, $24 \%$ disagreed, $15 \%$ uncertain, $9 \%$ agreed and $2.5 \%$ strongly agreed with statement that 'they speak English language fluently during classroom discussion'. Mean score 1.89 highlights that majority of the respondents disagreed that they can speak English language fluently during classroom discussion.

Table 4.5

Confidence during Classroom Participation in English

\begin{tabular}{|c|c|c|c|c|c|c|c|c|}
\hline $\mathrm{S} \#$ & Items & Options & SDA & DA & UN & A & SA & Mean \\
\hline \multirow[t]{2}{*}{1.} & I feel confident in speaking English & $\mathrm{f}$ & 74 & 108 & 114 & 52 & 52 & \multirow[t]{2}{*}{2.75} \\
\hline & $\begin{array}{l}\text { language during } \\
\text { participation. }\end{array}$ & $\%$ & 18.5 & 27 & 28.5 & 13 & 13 & \\
\hline \multirow[t]{2}{*}{2.} & Students hesitate during classroom & $\mathrm{f}$ & 9 & 15 & 24 & 125 & 227 & \multirow[t]{2}{*}{4.37} \\
\hline & $\begin{array}{l}\text { participation because they feel } \\
\text { students will laugh on their wrong } \\
\text { English. }\end{array}$ & $\%$ & 2.2 & 6.5 & 6 & 31.5 & 31.7 & \\
\hline \multirow[t]{2}{*}{3.} & Students from English medium & $\mathrm{f}$ & 11 & 32 & 44 & 158 & 155 & \multirow[t]{2}{*}{4.04} \\
\hline & $\begin{array}{l}\text { school speak English confidently } \\
\text { during classroom participation. }\end{array}$ & $\%$ & 2.8 & 8 & 11 & 39.5 & 38.8 & \\
\hline \multirow[t]{2}{*}{4.} & Students from Urdu medium schools, & $\mathrm{f}$ & 15 & 37 & 39 & 168 & 141 & \multirow[t]{2}{*}{3.96} \\
\hline & $\begin{array}{l}\text { hesitate during } \\
\text { participation. }\end{array}$ & $\%$ & 3.8 & 9.3 & 9.8 & 42 & 35.3 & \\
\hline
\end{tabular}

Table 4.5 Statement 1 indicates that the $18.5 \%$ respondents strongly disagreed, $27 \%$ disagreed, $28.5 \%$ uncertain, $13 \%$ agreed and $13 \%$ strongly agreed that 'they feel confident in speaking English language during classroom participation'. Mean score 2.75 presents that majority of the respondents uncertain that they feel in speaking English language confidently. Statement 2 shows that $2.25 \%$ respondents strongly disagreed, $3.75 \%$ disagreed, $6 \%$ uncertain, $31.5 \%$ agreed and $56.75 \%$ strongly agreed with statement that 'Students hesitate during in classroom participation because they feel students will laugh on their wrong English'. Mean score 4.37 also supported that majority of the respondents; $56.8 \%$ agreed that the problem is shyness. Statement 3 shows that $2.9 \%$ respondents strongly disagreed, $8.0 \%$ disagreed, $11 \%$ uncertain, $39.5 \%$ agreed and 38.8\% strongly agreed with statement that 'Students from English medium school speak English confidently during classroom participation'. Mean 
score 4.04 also supported that majority of the respondents $39.5 \%$ agreed that the Students of English medium schools speak English confidently. Statement 4 shows that 3.8\% respondents strongly disagreed, 9.3\% disagreed, $9.8 \%$ uncertain $42.0 \%$ agreed and $35.3 \%$ strongly agreed with statement that 'Students from Urdu medium schools hesitate during classroom participation'. Mean score 3.96 also supported that most of the respondents agreed that students of Urdu medium schools, feel hesitation.

Table 4.6

Role of Teacher and other Factors

\begin{tabular}{llccccccc}
\hline S\# & Items & Options & SDA & DA & UN & A & SA & Mean \\
\hline 1. & University teachers deliver the & $\mathrm{f}$ & 25 & 46 & 50 & 162 & 117 & 3.75 \\
& lecture in English language. & $\%$ & 6.3 & 11.5 & 12.5 & 40.5 & 29.3 & \\
& & & & & & \\
2. & Teachers motivate the students & $\mathrm{f}$ & 19 & 38 & 32 & 159 & 142 & 3.87 \\
& $\begin{array}{l}\text { for classroom participation. } \\
\text { 3. }\end{array}$ & $\%$ & 7.5 & 9.5 & 8 & 39.8 & 35.5 & \\
& $\begin{array}{l}\text { Students from Urdu medium } \\
\text { school, use grammar translation } \\
\text { method for classroom }\end{array}$ & $\mathrm{f}$ & 15 & 49 & 56 & 142 & 137 & 3.96 \\
& participation.
\end{tabular}

Table 4.6 statement 1 indicates that the $6.3 \%$ respondents strongly disagreed, $11.5 \%$ disagreed, $12.5 \%$ uncertain, $40.5 \%$ agreed and $29.3 \%$ strongly agreed with statement that 'University teachers deliver the lecture in English language'. Mean score 3.75 also supports the statement that majority of the respondents; $40.5 \%$ agreed that the teachers deliver the lecture in English. Statement 2 highlights that $7.5 \%$ respondents strongly disagreed, $9.5 \%$ disagreed $8 \%$ uncertain, $39.8 \%$ agreed and $35.5 \%$ strongly agreed with statement that 'Teachers motivate students for classroom participation'. Mean score 3.87 also supports that majority of the respondents $39.8 \%$ agreed that the teachers motivate the students for speaking English. Statement 3 indicates that 3.8\% respondents strongly disagreed, $12.3 \%$ disagreed, $14.0 \%$ uncertain, $35.5 \%$ agreed and $34.3 \%$ strongly agreed with statement that 'Students from Urdu medium school use grammar translation method for classroom participation'. Mean score 3.96 also supported the statement. So, most of respondents 35.5\% agreed that the Students of Urdu medium school, use translation method. 
Table 4.7

Suggestions to improve English Language Speaking

\begin{tabular}{|c|c|c|c|c|c|c|c|c|}
\hline S\# & Items & Options & SDA & DA & UN & A & SA & Mean \\
\hline \multirow[t]{2}{*}{1.} & \multirow{2}{*}{$\begin{array}{l}\text { Speaking of English language } \\
\text { must be compulsory at post } \\
\text { graduate level. }\end{array}$} & f & 9 & 13 & 5 & 111 & 262 & \multirow[t]{2}{*}{4.51} \\
\hline & & $\%$ & 2.5 & 3.3 & 1.3 & 27 & 65.5 & \\
\hline \multirow[t]{2}{*}{2.} & \multirow{2}{*}{$\begin{array}{l}\text { English subject must be } \\
\text { compulsory during every } \\
\text { semester. }\end{array}$} & f & 57 & 68 & 26 & 104 & 145 & \multirow[t]{2}{*}{3.35} \\
\hline & & $\%$ & 14.3 & 17 & 6.5 & 26 & 36.3 & \\
\hline \multirow[t]{2}{*}{3.} & \multirow{2}{*}{$\begin{array}{l}\text { University must provide extra } \\
\text { classes of English language. }\end{array}$} & $\mathrm{f}$ & 23 & 40 & 40 & 129 & 168 & \multirow[t]{2}{*}{3.95} \\
\hline & & $\%$ & 5.8 & 10 & 10 & 32.3 & 42 & \\
\hline \multirow[t]{2}{*}{4.} & \multirow{2}{*}{$\begin{array}{l}\text { Teachers must fine the students if } \\
\text { do not participate in English } \\
\text { during classroom activities. }\end{array}$} & $\mathrm{f}$ & 55 & 74 & 58 & 108 & 105 & \multirow[t]{2}{*}{3.34} \\
\hline & & $\%$ & 13.8 & 18.5 & 14.5 & 27 & 26.3 & \\
\hline
\end{tabular}

Table 4.7 statement 1 shows that the $2.3 \%$ respondents strongly disagreed, $3.3 \%$ disagreed, $1.3 \%$ uncertain, 27.8 agreed and $65.5 \%$ strongly agreed with statement that 'Speaking of English language must be compulsory at post graduate level'. Mean score 4.51 also supported that majority of the respondents; 65.5\% strongly agreed that English language must be compulsory. Statement 2 indicates that $14.3 \%$ respondents strongly disagreed, $17.0 \%$ disagreed, $6.5 \%$ uncertain, $26.0 \%$ agreed and $36.3 \%$ strongly agreed with statement that 'English subject must be compulsory during every semester'. Mean score 3.35 also supports that majority of the respondents $36.3 \%$ agreed that the subject of English language is necessary for improvement. Statement 3 shows that 5.8\% respondents strongly disagreed, $10 \%$ disagreed, $10 \%$ uncertain, $32.3 \%$ agreed and $42.0 \%$ strongly agreed with statement that 'University must provide extra classes of English language'. Mean score 3.95 also supports that majority of the respondents $42.0 \%$ agreed that there must be some extra classes on English speaking. Statement 4 shows that the $13.8 \%$ respondents strongly disagreed, $18.5 \%$ disagreed, $14.5 \%$ uncertain, $27.0 \%$ agreed and $26.3 \%$ strongly agreed with statement that 'Teachers must fine the students if do not participate in English during classroom activities'. Mean score 3.34 also supported that majority of the respondents; $27.0 \%$ agreed that the students have to pay fine if they do not follow the rule.

\section{Discussion}

According to the results of the study majority of the respondents disagreed that they have rich vocabulary and they can use appropriate English vocabulary according to the topic of discussion. Additionally, Akram and Nosheen (2013) described that mostly students feel problem while communicating in English language due to lack of English vocabulary. 
Furthermore, majority of students use simple language because of insufficient vocabulary of English language. Which is in turn the cause of students' lack of classroom participation and majority of the respondents follow the grammatical rules. Results of the study explored that most of the respondents do so many mistakes in speaking English language during classroom participation. Furthermore, Khan and Ali (2010) elaborated that most of time teaching English language just considered as the educational subject instead of language. So, students do not try to learn they just use rote memorization to pass the exam. Moreover, grammar illiteracy, lack of proper accent and pronunciation and influence of mother tongue is the hurdle for students in classroom participation. Majority of the respondents cannot speak English language fluently during classroom discussion; they feel lack of confidence and shy during speaking English language. In addition, students feel anxiety during conversation in English language which mostly affects their educational activities and academic grades (Ahmad, Pathan \& Khan 2017). Moreover, majority of the respondents feel that students of English medium schools speak English confidently than the students those have read in Urdu medium schools because they feel hesitation. Respondents agreed that the teachers deliver the lecture and communicate with students in English and motivate the students to participate in classroom by using English language. However, majority of the respondents are in favor of that there should be a compulsory course of English in every semester, respondents also agreed on that there should be extra classes on speaking English language and it should be obligatory for the students to speak English during classroom discussion otherwise teacher will fine them. Mansoor (2013) revealed that students show the interest in learning English language and they are motivated to learn but the educational sectors and government do not support them.

\section{Conclusion}

This study was designed to explore the problems of students during classroom participation. According to the first objective of the study problems of university students in speaking English during classroom participation, majority of the respondents agreed that they feel problem during classroom participation due to insufficient vocabulary and lack of grammatical knowledge of English language so they do lots of mistakes and it reduces their confidence and demotivate them for speaking English during classroom participation. Furthermore, according to the second objective of the study regarding factors affecting the students in speaking English during classroom participation, majority of the respondents responded that they do not participate in class because they feel shy and think that students from English medium schools can speak properly and confidently than the students from Urdu medium schools. 
Students feel shyness in speaking English because they think if they will speak wrong English. Furthermore, study revealed that mother tongue creates the problems for the students because first of all they translate the sentence into English from mother tongue.

\section{Recommendations}

1. The results of the study recommend that teachers may encourage the students; to participate in class during classroom discussion, and to use English dictionary to enhance their vocabulary and grammatical knowledge of English language.

2. Furthermore, study also recommends that teachers should motivate students who do not participate in class because they feel shy and think that students from English medium schools can speak properly and confidently than the students from Urdu medium schools.

\section{References}

Ahmad, A., Pathan, Z. H., \& Khan, F. S. (2017). Exploring the Causes of English Language Speaking Anxiety among Postgraduate Students of University of Balochistan. International Journal of English Linguistics, 7(2), 99105.

Akram, M. \& Nosheen, S. S. (2013). A study to analyze the problems of post graduate students in speaking English language at The Islamia University of Bahawalpur, Pakistan. Proceeding of the Global Summit on Education (GSE2013), Kuala Lumpur.

Ayokanmbi, F. M. (2011). Competencies for global engineers and technologists. Journal of Industrial technology, 27(1), 1-6.

Al-Siba, D. (2004). Promoting oral fluency of second language learners: Educational Linguistics. Department of English, King Saud University.

Boonkit, K. (2010). Enhancement and the Development of Speaking Skills for non-native Speakers of English. Journal of Social and Behavioral Science, 2, 765-770.

Brantmier, C. (2008). Meeting the demands: the circularity of remodeling foreign language programs. The modern language journal, 92(2), 306-309. 
Gan, Z. (2012). Understanding L2 Speaking Problems: Implications for ESL Curriculum Development in a Teacher Training Institution in Hong Kong. .Australian Journal of Teacher Education, 37(1).

Hartsell, T. \&. (2016). Video streaming in online learning. AACE Journal, 14(1), $31-43$.

Khan, N., \& Ali, A (2010). Improving the speaking ability in English: The students' perspective. Procedia Social and Behavioral Sciences, 2(2), 3575-3579.

Kocak, M. (2010). A novice teacher's action research on EFL learner's speaking anxiety. Journal of Social and Behavioral Science, 3, 138-143.

Liu, M.., \& Jackson, J. (2008). An exploration of Chinese EFL learners 'unwillingness to communicate and foreign language anxiety. Modern Language Journal, 92, 71-86.

Mansoor, S. (2004). The status and role of regional languages in higher education in Pakistan. Journal of Multilingual and Multicultural Development, 25(4), 333-353.

Nunan, D. (2003). The Impact of English as a Global Language on Educational Policies and practices in the Asia-Pacific Region. TESOL Quarterly, 37(4), 589-613

Patsy, L., \& Spada, N. M. (2011). How languages are learned: Oxford handbooks for language teachers. Oxford University Press.

Sharma, O. K. (2004). Principles of Education. New Delhi: Deep and Deep Publications Pvt. Ltd.

Teng, B., \& Sinwongsuwat, K. (2015). Teaching and Learning English in Thailand and the Integration of Conversation Analysis (CA) into the Classroom. English Language Teaching, 8(3), 13-23.

Wolff, M., \& Qiang, N. (2009). Teaching EFL in China. New York: Nova Science Publishers.

Yegani, H., \& Jodaei, H. (2017). The Effect of Task-based and Topic-based Speaking Activities on Speaking Ability of Iranian EFL Learners. 
International Journal of Innovation in Teaching and Learning (IJITL)

Volume V- Issue II (Dec 2019)

International Journal of English Language \& Translation Studies, 5(4), 85-93.

Zhang, Y. (2009). Reading to speak: Integrating oral communication skills. English Teaching forum, 1(1), 31-34.

\section{Citation of this Article:}

Nosheen, S. S., Akram, M., \& Javed, M. (2019). Problems of University Students in Speaking English during Classroom Participation. International Journal of Innovation in Teaching and Learning (IJITL), 5(2), 64-78. 